\title{
Avian Influenza in Wild Birds from South America: Review, Implications and Perspectives
}

\author{
Renata Hurtado $^{1 *}$ and Ralph Eric Thijl Vanstreels ${ }^{2}$ \\ ${ }^{1}$ Department of Preventive Veterinary Medicine and Animal Health, School of Veterinary Medicine, University of São Paulo, São Paulo, \\ Brazil; ${ }^{2}$ Laboratory of Wildlife Comparative Pathology, Department of Pathology, School of Veterinary Medicine, University of São
} Paulo, São Paulo, Brazil

\begin{abstract}
Avian influenza viruses (AIVs) have been recorded in a broad variety of hosts, including humans, terrestrial and marine mammals, and domestic and wild birds. Wild aquatic birds are recognized as the chief natural reservoirs of AIV, and their migratory flyways can serve as routes for the dispersion of the virus across countries and continents. Although AIV is one of the most studied pathogens in the world, studies on the ecology and epidemiology of this virus in South America are few and fragmented. In this review, we examine the current state of the art on the epidemiology of AIV in wild birds in South America. Current evidence corroborates that many of the broad epidemiological patterns that have been documented in other continents, such as the role played by Anseriformes and Charadriiformes in the maintenance and spread of AIV, are also true in South America. On the other hand, the fact that AIV prevalence in South American studies appears to be remarkably lower than that observed in other continents, along with the presence of endemic taxa of birds that may be highly susceptible to AIV, indicates that South America may have distinct characteristics that modulate the epidemiology of AIV in unique ways. However, our knowledge on the occurrence of AIV in South America is still limited and there are important gaps in the species and geographic distribution of the sampling effort.
\end{abstract}

\section{Introduction}

Avian influenza viruses (AIVs) are members of the genus Influenzavirus A (Orthomyxoviridae) and contain 8 negative-sense RNA segments. These viruses are classified in subtypes based on the antigenic properties of the two glycoproteins expressed on the viral envelope, hemagglutinin (HA) and neuraminidase (NA). To date, 16 HA subtypes (H1-H16) and 9 NA subtypes (N1-N9) have been described in birds and can be found in multiple combinations. ${ }^{1,2}$

Keywords: Birds; Wildlife; Avian influenza virus; Epidemiology; Zoonosis; Public health.

Abbreviations: AIV, avian influenza virus; HA, hemagglutinin; HI, hemagglutination inhibition; HPAI, high pathogenicity avian influenza; LPAI, low pathogenicity avian influenza; LPNAI, low pathogenicity notifiable avian influenza; NA, neuraminidase; rRT-PCR, real-time reverse transcription polymerase chain reaction.

Received: October 02, 2016; Revised: December 04, 2016; Accepted: December 08, 2016

DOI: 10.14218/ERHM.2016.00014

${ }^{*}$ Correspondence to: Renata Hurtado, Department of Preventive Veterinary Medicine and Animal Health, School of Veterinary Medicine, University of São Paulo, Av. Prof. Dr. Orlando Marques de Paiva 87, 05508-270, São Paulo, Brazil. Tel: +55-1195294-0219,E-mail: renata_fh@yahoo.com.br
Novel HA and NA subtypes (H17-H18 and N10-N11) were recently described in Influenzavirus $A$ from bats in South America, however current evidence indicates these subtypes might not be able to infect birds even though they can infect human and canine cells in vitro. ${ }^{3-5}$

The first suspected human cases of influenza date back to the writings of Hippocrates in 410 B.C., and since then a number of epidemics and 11 pandemics have occurred. ${ }^{6,7}$ The most devastating was the "Spanish flu", an H1N1 pandemic that killed approximately 50 million people in $1918 .{ }^{8,9}$ More recently, the H1N1 pandemic of 2009 claimed the lives of 284,500 people. $^{10}$

AIVs have been recorded in a broad variety of hosts, including humans, terrestrial and marine mammals, and domestic and wild birds. Aquatic birds are recognized as the chief natural reservoirs of AIV, especially those from the orders Anseriformes (e.g. teals, ducks, geese and swans) and Charadriiformes (e.g. shorebirds, gulls and terns). ${ }^{11,12}$ Most AIV infections in these avian taxa are subclinical or accompanied by only mild clinical signs, and as a result they are effective reservoirs of infection and play a central role in the ecology and evolution of AIV. ${ }^{11-14}$ Studies in North America have shown that Anseriformes are central to the long-term persistence of AIV, while migratory Charadriiformes play a role in the short-term dissemination of the virus over long distances. ${ }^{15}$ Furthermore, because birds do not recognize geopolitical borders, their migratory flyways can serve as routes for the dispersion of the virus across countries and continents. ${ }^{11}$

While the ecology of AIV has been extensively studied in North America, much less information is available for South America. There are major flyways connecting South and North America, whereas migratory routes connecting South America to other continents are not as common. ${ }^{13,16}$ It is, therefore, reasonable to expect that the genetics and ecology of AIV in South America resembles those of the virus in North America. However, because North and South America differ substantially in terms of their avian communities, ecosystems and environmental conditions, differences in ecology and epidemiology may also be expected to occur.

In this review, we examine the current state of the art on the epidemiology of AIV in wild birds in South America, evaluating how the available information compares to what is known about the virus in North America and elsewhere, discussing the implications for public health, the poultry industry and wildlife conservation, and identifying limitations of and gaps in the knowledge to be addressed in future studies.

Early studies in South America

Most studies investigating the occurrence of AIV in wild birds 


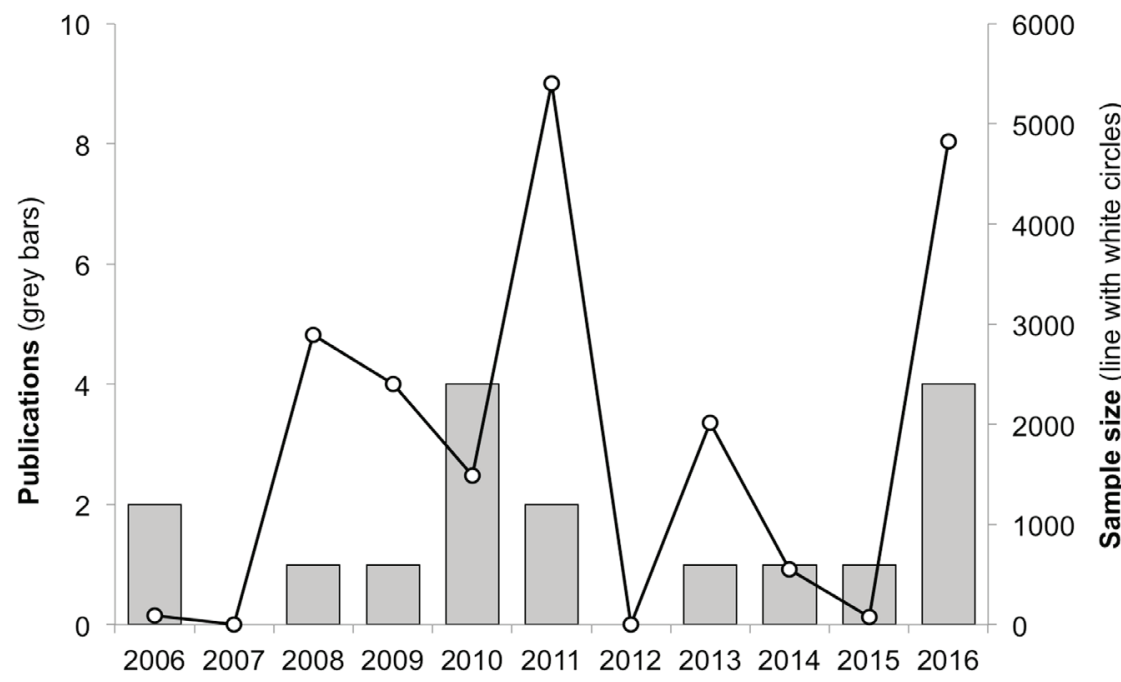

Fig. 1. Historical trends of the number of publications and combined sample size of published studies on the occurrence of AIV in wild birds in South America, 2006-2016.

in South America were conducted in the last decade, with only a small number of studies conducted prior to 2005 , all of them in Brazil. These early studies employed methods that are either no longer used in recent studies, such as viral isolation in cell cultures or serological testing for which there are no recent studies for comparison, or obtained atypical results that merit to be considered separately. ${ }^{17-19}$

The first studies on the occurrence of AIV in South America were conducted by Couceiro et al., who collected samples from 107 white-faced whistling-ducks (Dendrocygna viduata) and 39 ornamental birds in Rio de Janeiro from 1978 to 1979, and isolated AIV from $13(12.1 \%)$ and $5(17.2 \%)$ samples, respectively. ${ }^{20,21}$ The strains were isolated following inoculation in embryonated eggs, and were confirmed as AIV by double immunodiffusion. Hemagglutination inhibition (HI) revealed that the strains were inhibited by serums against subtype $\mathrm{H} 6$ or, for one strain, against subtype $\mathrm{H7}$.

Research on AIV in wild birds in Brazil would be continued only two decades later, in 1997-1998, when Kawamoto et al. sampled 37 wild birds in the São Paulo state. ${ }^{17}$ In that study, AIV was isolated in cell culture (MDCK and NCIH 292) from 15 birds $(40.5 \%)$, corresponding to $37.5 \%$ of the ruddy ground-doves (Columbina talpacoti, $n=8$ ) and all the red-eyed vireos (Vireo olivaceus, $n=3$ ), red-cowled cardinals (Paroaria dominicana, $n=2$ ), double-collared seedeaters (Sporophila caerulescens, $n=1$ ) and lined seedeaters (Sporophila lineola, $n=1$ ) sampled in that study. The presence of AIV was confirmed by HI testing and real-time reverse transcription polymerase chain reaction (rRT-PCR), and all strains were later characterized as H3N2.22,23 On the other hand, Soares et al. used the same methods but did not detect AIV in 86 ducks (Anatidae) captive at the São Paulo zoo. ${ }^{22}$

In 2004, the Brazilian Ministry of Health conducted two surveys for influenza virus in wild birds. The first study examined wild birds of Galinhos, Rio Grande do Norte state. ${ }^{24}$ A total of 381 Charadriiformes (Charadriidae and Scolopacidae) and 7 grounddoves (Columbina sp.) were sampled, and AIV isolation in embryonated eggs was attempted. Because samples were pooled for testing, the apparent prevalence could not be clearly established. However, the pool of ground-dove samples and 12 of 21 pools (57.1\%) of shorebird samples showed positivity to AIV, and HI testing indicated all isolates corresponded to subtype H3. The sec- ond study employed similar methods to test wild birds of Lagoa do Peixe, Rio Grande do Sul state, comprising: 169 Charadriiformes (Charadriidae, Laridae, Recurvirostridae, Rynchopidae, Scolopacidae), two Passeriformes and one Podicipediformes. ${ }^{25}$ Four of seven pools $(57.1 \%)$ of shorebird samples showed positivity to AIV, and HI testing indicated two isolates corresponded to subtype $\mathrm{H} 2$ and the other two corresponded to subtype H4.

It is significant that these early studies identified percentages of positive samples that were significantly higher than those usually recorded in studies from other continents and in later studies conducted in South America. ${ }^{11,14}$ Possible explanations to such unusually high prevalence include suboptimal specificity of early diagnostic methods, field or laboratory contaminations, or the possibility that the samples obtained represented epizootic or otherwise unusual epidemiological conditions.

Therefore, because these early studies are in contrast with the findings of recent studies and might not faithfully represent the epidemiology of AIV in wild birds in South America, the remainder of this review will address only studies that have been published in the last decade, from 2006 to 2016 (inclusive).

\section{Recent studies of AIV in South America}

Eighteen studies investigating the occurrence of AIV in wild birds in South America were published from 2006 to 2016 (Supplementary File S1). The publication of these studies did not follow an evident historical trend, with an irregular number of publications and sampling effort from year to year (Fig. 1). Such lack of a constant or gradual increase in the number of publications or sample size is likely a reflection of the fact that most studies were conducted as short-term research efforts of small academic groups rather than as long-term governmental or multi-institutional AIV surveillance programs.

From 2006 to 2016, most publications investigated AIV in wild birds sampled in Brazil, Argentina and Peru (Table 1). From a total of 19,755 samples tested in the continent during this period, 17,389 samples $(88 \%)$ had been collected in these three countries, illustrating the strong bias in the sampling effort. When the accumulated sample sizes are contrasted with the area and number of 
Hurtado R. et al: Avian Influenza in Wild Birds from South America

Table 1. Summary of the number of publications, sampling effort and AIV isolates from wild birds in South America from 2006 to 2016 , by country

\begin{tabular}{|c|c|c|c|c|c|}
\hline \multirow{2}{*}{ Country } & \multirow{2}{*}{ Area $\left(\mathrm{km}^{2}\right)$} & \multirow{2}{*}{ Bird species } & \multicolumn{3}{|c|}{ AIV research } \\
\hline & & & Publications & Sample size & Isolates \\
\hline Argentina & $2,780,400$ & 1,035 & 3 & 7,504 & 10 \\
\hline Bolivia & $1,098,580$ & 1,425 & 2 & 93 & 1 \\
\hline Brazil & $8,515,767$ & 1,832 & 8 & 2,998 & 7 \\
\hline Chile & 756,950 & 527 & 2 & 79 & 5 \\
\hline Colombia & $1,197,411$ & 1,923 & 1 & 2,013 & 2 \\
\hline Ecuador & 283,560 & 1,675 & 0 & - & - \\
\hline French Guiana & 91,000 & 727 & 0 & - & - \\
\hline Guyana & 214,970 & 796 & 0 & - & - \\
\hline Paraguay & 406,750 & 719 & 0 & - & - \\
\hline Peru & $1,285,220$ & 1,828 & 3 & 6,887 & 31 \\
\hline Suriname & 163,270 & 728 & 0 & - & - \\
\hline Uruguay & 176,220 & 470 & 1 & 181 & 0 \\
\hline Venezuela & 912,050 & 1,405 & 0 & - & - \\
\hline Total & $17,882,148$ & 3,505 & 18 & 19,755 & 56 \\
\hline
\end{tabular}

The area and numbers of bird species of each country were obtained respectively from UNSD and Lepage. ${ }^{26,27}$ Numbers of publications from different countries overlap because one publication provides information relating to multiple countries. ${ }^{50}$

bird species of each country, it becomes evident that their distribution is not proportional to the territory of each country nor is it a fair representation of their avian diversity. ${ }^{26,27}$ In fact, nearly half of the countries of South America lack published studies on the occurrence of AIV in their wild birds. For instance, Colombia ranks first in avian diversity in the world, with 1,923 known bird species, and yet only one such study has been published to date. Similarly, Ecuador and Venezuela are also among the top five countries with highest avian diversity in South America, with respectively 1,675 and 1,405 bird species, and yet have not been the subject of publications on the occurrence of AIV in their wild birds. To place this in perspective, the United States and Canada have respectively 1,146 and 690 bird species. $^{27}$

The distribution of AIV studies is uneven in relation to the taxonomical orders of the wild birds that were studied (Table 2). Because several publications fail to provide details on the number of individuals sampled for each avian species, it is not possible to determine the taxonomical order of the birds from which 7,018 samples were obtained ( $35.5 \%$ of the sampling effort). For the remaining samples, the orders Anseriformes and Charadriiformes were the most frequently targeted species, corresponding respectively to $48.3 \%$ and $29.1 \%$ of the samples tested for AIV. Smaller but still significant numbers of samples $(>500)$ were evaluated for the orders Pelecaniformes $(6.4 \%)$, Sphenisciformes $(6.3 \%)$ and Suliformes (5.4\%), all of which comprise aquatic species of birds.

The emphasis in Anseriformes and Charadriiformes is not surprising considering that these orders of aquatic birds are well known for their central role in the epidemiology of AIV in other continents. ${ }^{11,28}$ However, because the avian communities of South America are vastly different from those of the Northern Hemisphere, caution is advised not to presume that AIV epidemiology in the Neotropics will be identical to that observed in other well-studied continents. Other aquatic birds that may live in close proximity with Anseriformes and Charadriiformes should be investigated as they could potentially be involved in the maintenance and transmission of AIV. For instance, recent studies have found that penguins (Sphenisciformes) play an important role along with Charadriiformes in the persistence and evolution of AIV in Antarctica, a dynamic that could not have been witnessed in studies conducted in the Northern Hemisphere since penguins do not occur there. ${ }^{29,30}$ Inversely, murres and auklets (Alcidae) play an important role in AIV transmission in the Northern Hemisphere but are absent in the Southern Hemisphere. ${ }^{31,32}$

Furthermore, even though it is reasonable to consider aquatic birds as prime candidates for AIV surveillance in South America, the role of terrestrial birds as reservoirs of AIV should not be dismissed. It is worth highlighting that Alvarez et al. documented an outbreak of AIV subtype H1N1 in wild red-winged tinamous (Rhynchotus rufescens). ${ }^{33}$ This record corresponded to the first record of AIV in Tinamiformes, an order of non-migratory grounddwelling birds that is endemic to Central and South America, which illustrates the need to investigate the occurrence of AIV in taxonomical groups that would not traditionally be expected to play a significant role in the epidemiology of these viruses.

When the geographic distribution of the sampling effort is examined in relation to the ecoregions of South America (Fig. 2, Supplementary File S1), another limitation of our current knowledge of AIV epidemiology in South America becomes evident. Of the 109 terrestrial ecoregions of continental South America (as classified by Olson et al.), to date only 16 ecoregions $(14.7 \%$ ) had wild birds tested for AIV. ${ }^{34}$ Because these ecoregions have distinct avian assemblages and environmental conditions, the prevalence and epidemiology of AIV may differ considerably among these areas, and comparative epidemiological studies have yet to be conducted.

Less than $0.1 \%$ of the AIV strains for which there are gene sequences in publicly-available databases correspond to viruses identified in avian hosts from South America. ${ }^{29,35}$ Unsurprisingly, the number of AIV isolates from South American wild birds has been historically correlated to the sampling effort accumulated by different studies (Fig. 3). This corroborates the interpretation that the small number of isolates is related to the proportionally smaller sampling effort that has been historically dedicated to the 
Hurtado R. et al: Avian Influenza in Wild Birds from South America

Table 2. Distribution of the published sampling effort (swabs and environmental fecal samples) for wild birds tested for AIV in South America from 2006 to 2016, by country and host taxonomic order

\begin{tabular}{|c|c|c|c|c|c|c|c|c|}
\hline Taxonomic order & Argentina & Bolivia & Brazil & Chile & Colombia & Peru & Uruguay & Total \\
\hline Accipitriformes (68 spp.) & & & 2 & & & & & 2 \\
\hline Anseriformes (58 spp.) & $5,118[8]$ & & 96 & & $592[2]$ & $350[3]$ & & $6,156[13]$ \\
\hline Caprimulgiformes (333 spp.) & & & 3 & & 4 & & & 7 \\
\hline Cariamiformes (2 spp.) & & & & & & & & 0 \\
\hline Charadriiformes (147 spp.) & $728[1]$ & & $1,462[4]$ & $79[5]$ & 327 & $1,112[5]$ & & $3,708[15]$ \\
\hline Ciconiiformes (3 spp.) & & & & & 1 & & & 1 \\
\hline Columbiformes (59 spp.) & 14 & & 29 & & & & & 43 \\
\hline Coraciiformes (16 spp.) & & & 2 & & 11 & & & 13 \\
\hline Cuculiformes (23 spp.) & & & & & 2 & & & 2 \\
\hline Eurypygiformes (1 sp.) & & & & & & & & 0 \\
\hline Galbuliformes (54 spp.) & & & 1 & & & & & 1 \\
\hline Galliformes (66 spp.) & & & & & 3 & & & 3 \\
\hline Gruiformes (56 spp.) & 22 & & & & & 100 & & 122 \\
\hline Opisthocomiformes (1 sp.) & & & & & & & & 0 \\
\hline Passeriformes (2024 spp.) & 45 & & 195 & & 31 & & & 271 \\
\hline Pelecaniformes (44 spp.) & 8 & & 3 & & 343 & $461[1]$ & & $815[1]$ \\
\hline Piciformes (134 spp.) & & & & & 1 & & & 1 \\
\hline Podicipediformes (10 spp.) & & & & & & & & 0 \\
\hline Procellariiformes (92 spp.) & 18 & & 1 & & & & & 19 \\
\hline Psittaciformes (131 spp.) & & & 2 & & & & & 2 \\
\hline Rheiformes (2 spp.) & & & 1 & & & & & 1 \\
\hline Sphenisciformes (17 spp.) & 806 & & & & & & & 806 \\
\hline Strigiformes (45 spp.) & & & 1 & & & & & 1 \\
\hline Suliformes (23 spp.) & 304 & & & & & 382 & & 686 \\
\hline Tinamiformes (45 spp.) & $77[1]$ & & & & & & & $77[1]$ \\
\hline Trogoniformes (18 spp.) & & & & & & & & 0 \\
\hline Order not specified & 364 & $93[1]$ & $1,200[3]$ & & 698 & $4,482[22]$ & 181 & $7,018[26]$ \\
\hline Total & $7,504[10]$ & $93[1]$ & $2,998[7]$ & $79[5]$ & $2,013[2]$ & $6,887[31]$ & 181 & $19,755[56]$ \\
\hline
\end{tabular}

Numbers within brackets indicate the number of AIV strains isolated and/or confirmed through gene sequencing. The number of species recorded in South America for each order was obtained from Lepage. ${ }^{27}$

continent.

However, even when this limitation is taken into account, current evidence also suggests that AIV prevalence might be relatively lower in South America than in North America and elsewhere. In a global review, Olsen et al. found that AIV prevalence was $7.7 \%$ for Anseriformes $(n=44,318)$ and $1.2 \%$ for Charadriiformes $(n=19,663) .{ }^{11}$ Similar levels of prevalence were consistently found in regional studies in North America. ${ }^{13,14}$ In comparison, studies in South America have found an overall prevalence of $0.21 \%$ in Anseriformes (range: $0.25-0.86 \%$ ) and $0.32 \%$ in Charadriiformes (range: $0.21-3.80 \%$ ) (Table 3). ${ }^{33,35-44}$ It is worth noting that Mathieu et al. stands out among South American studies for having found a slightly higher AIV prevalence (3.8\%), which is probably related to the fact that this study investigated gulls that had been found dead, as opposed to actively capturing healthy birds in their natural habitat. ${ }^{36}$

The reasons as to why South American wild birds appear to have a lower prevalence of AIV are unclear, and future studies will be necessary to confirm whether this is a widespread pattern and identify possible causes, or to dismiss the possibility that this reflects differences in sample collection season or storage. A possible explanation is that South America has a relatively lower diversity of Anseriformes (North America has 74 spp. and South America has 58 spp., of which $26 \mathrm{spp}$. are shared) and Charadriiformes (North America has 185 spp. and South America has 147 spp., of which 109 species are shared). ${ }^{27}$ Another factor at play may be the differences in families and subfamilies that each continent harbors. For Anseriformes, North America has more species in the subfamilies Anserinae (20 spp. and $3 \mathrm{spp}$. in North and South America, respectively) and Merginae (18 spp. and $3 \mathrm{spp}$.) and less species in the subfamily Tadorninae ( $1 \mathrm{sp}$. and $7 \mathrm{spp}$.) and species for which the taxonomy is unresolved ( 3 spp. and 9 spp.); species of the Anatinae subfamily are equally represented in both continents (18 spp. and $20 \mathrm{spp}$.). ${ }^{27,45}$ For Charadriiformes, the main difference that stands 


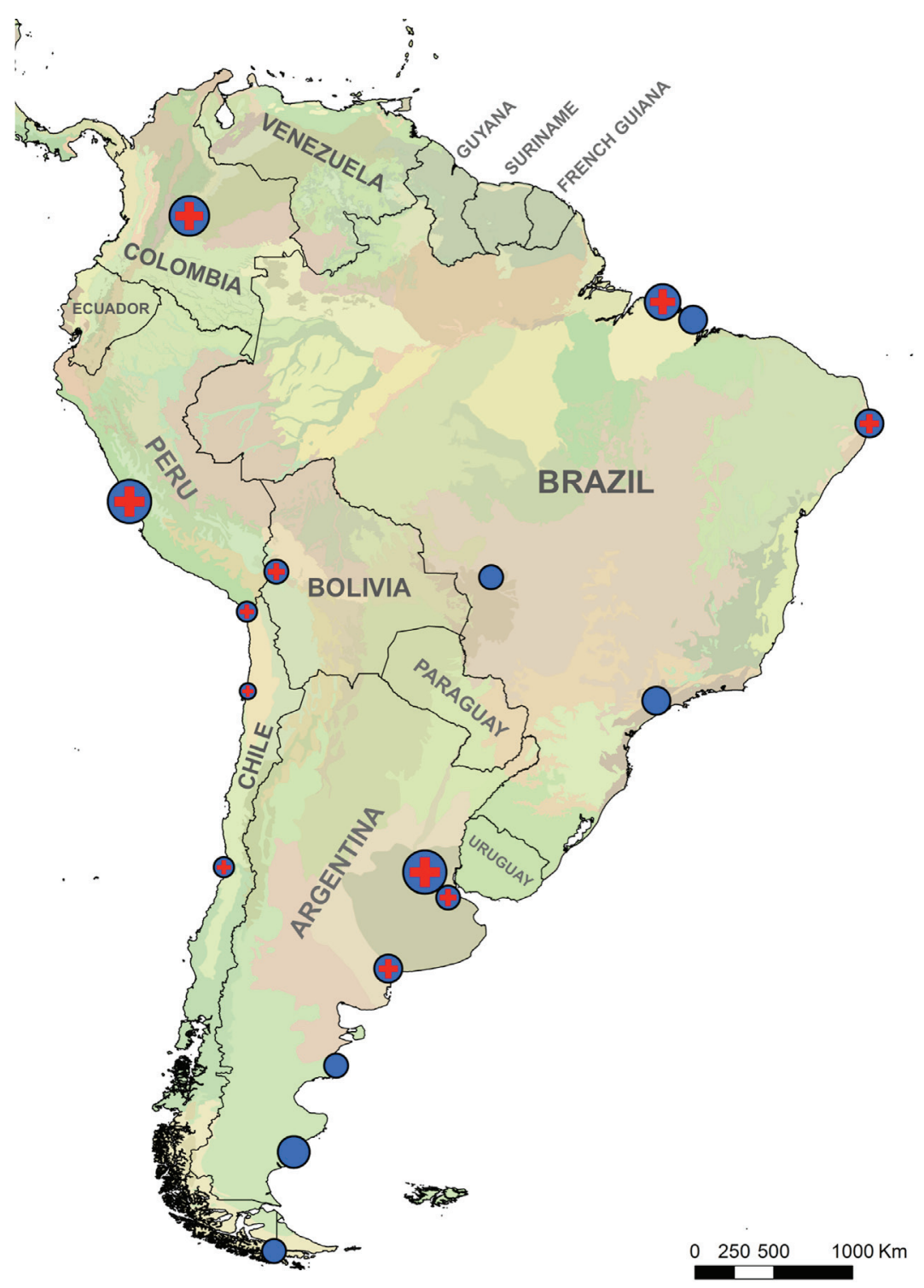

Fig. 2. Geographic distribution of studies on the occurrence of AIV in wild birds in South America, 2006-2016. Studies are represented in blue circles, with the sizes being proportional to the sample size examined and red crosses indicating locations where AIV strains were confirmed/isolated. Shades of green and brown on the background illustrate the terrestrial ecoregions. ${ }^{34}$

out is that the Alcidae family, a group that is well documented for carrying AIV, is represented by $23 \mathrm{spp}$. in North America while being absent from South America. 27,31,32

\section{AIV isolates and subtypes}

Studies published from 2006 to 2016 have produced 56 AIV isolates from wild birds in South America (Supplementary File S2). The subtype of HA and NA could not be determined for one and four isolates, respectively. The remaining isolates represent 23 antigen combinations (Table 4). The most frequent HA subtypes identified to date are H13 (18.2\%), H3 (14.5\%) and H6 (12.7\%), whereas N2 $(28.8 \%)$ and N9 $(26.9 \%)$ are the most frequent NA subtypes. Only HA subtypes H8, H14, H15 and H16 and NA sub- type N4 have yet to be recorded in wild birds in South America; this is unsurprising as these subtypes are generally rare, with the exception of N4 in Charadriiformes. ${ }^{13}$

The distribution of HA and NA subtypes among Anseriformes and Charadriiformes is generally similar in South and North America (based on data summarized by Krauss et al.) (Fig. 4). ${ }^{13}$ However, there are a few exceptions. It may be noted that South American AIV strains had a relatively higher frequency of subtypes H13 and N1 in Charadriiformes, N2 in Anseriformes, and N9 in both Anseriformes and Charadriiformes. On the other hand, while N6 is relatively frequent in Anseriformes from North America, as are H9 and N4 in Charadriiformes, these subtypes have yet to be recorded in those avian orders in South America. The reasons for these discrepancies are not known, and while they could reflect actual differences in AIV epidemiology they could also be 
Hurtado R. et al: Avian Influenza in Wild Birds from South America

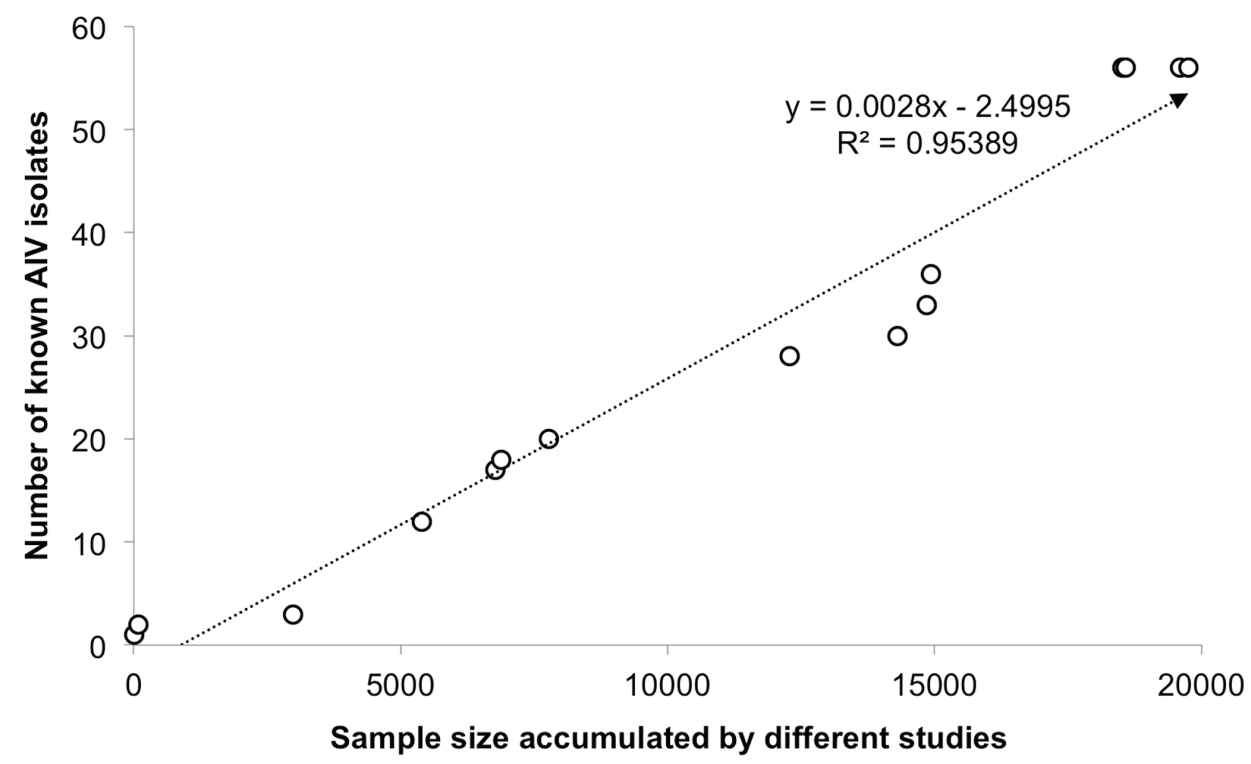

Fig. 3. Relationship between the published sample size and number of AIV strains from wild birds in South America from 2006 to 2016 . Each dot represents the state of knowledge at the time of publication of a study, which were included in chronological order of publication.

related to differences in the distribution of the sampling effort in the different species/families within each order. For instance, it is well established that in North America the subtype H13 is more frequently found in gulls than in other Charadriiformes, a pattern that also seems to occur in South America (70\% of the H13 strains recorded for this continent had been obtained from gulls). ${ }^{46,47}$ It is, therefore, reasonable to suspect that the higher percentage of H13 isolates in South America than in North America may reflect a greater proportion of gulls having been sampled in South America.

All H5 or H7 strains isolated in South America to date were found to have low pathogenicity, as determined by sequence analy- sis of the HA cleavage site and/or inoculation experiments. ${ }^{37,38,48-51}$ However, the H7N3 strain identified from cinnamon teals (Anas cyanoptera) by Spackman et al. merits further consideration. ${ }^{48,49}$ This strain had an HA cleavage site sequence indicative of low pathogenicity, and infection experiments corroborated its low pathogenicity to chickens and turkeys. However, its HA gene sequence was virtually identical to that of a highly pathogenic H7N3 strain identified in chickens in Chile 1 year later, suggesting that a genetic shift occurred with the insertion of 30 nucleotides at the HA cleavage site. This case, therefore, corroborates that low pathogenicity strains circulating in wild birds can undergo genetic

Table 3. Apparent prevalence of AIV in studies of wild Anseriformes and Charadriiformes in South America from 2006 to 2016

\begin{tabular}{|c|c|c|c|c|}
\hline \multirow{2}{*}{ Country and references } & \multicolumn{2}{|c|}{ Anseriformes } & \multicolumn{2}{|c|}{ Charadriiformes } \\
\hline & Prevalence & $n$ & Prevalence & $n$ \\
\hline \multicolumn{5}{|l|}{ Argentina } \\
\hline Pereda et al..$^{40}$ & $0 \%$ & 1,860 & $0.21 \%$ & 485 \\
\hline Alvarez et al. ${ }^{33}$ & $0 \%$ & 25 & - & - \\
\hline Rimondi et al., ${ }^{41} \mathrm{Xu}$ et al. ${ }^{42}$ & $0.25 \%$ & 3,233 & $0 \%$ & 243 \\
\hline \multicolumn{5}{|l|}{ Brazil } \\
\hline Araújo et al. ${ }^{39}$ Hurtado et al. ${ }^{35}$ & - & - & $0.54 \%$ & 556 \\
\hline Pinto et al. ${ }^{44}$ & $0 \%$ & 2 & $0 \%$ & 1 \\
\hline Hurtado et al. $^{43}$ & $0 \%$ & 94 & $0 \%$ & 905 \\
\hline \multicolumn{5}{|l|}{ Chile } \\
\hline Mathieu et al..$^{36}$ & - & - & $3.80 \%$ & 79 \\
\hline \multicolumn{5}{|l|}{ Colombia } \\
\hline Karlsson et al. ${ }^{38}$ & $0.34 \%$ & 592 & $0 \%$ & 327 \\
\hline \multicolumn{5}{|l|}{ Peru } \\
\hline Ghersi et al. ${ }^{37}$ & $0.86 \%$ & 350 & $0.45 \%$ & 1,112 \\
\hline Total & $0.21 \%$ & 6,156 & $0.32 \%$ & 3,708 \\
\hline
\end{tabular}


Hurtado R. et al: Avian Influenza in Wild Birds from South America

Table 4. Summary of the number of published AIV strains with each combination of hemagglutinin (HA) and neuraminidase (NA) retrieved from wild birds in South America from 2006 to 2016

\begin{tabular}{|c|c|c|c|c|c|c|c|c|c|c|c|}
\hline & N1 & N2 & N3 & N4 & N5 & N6 & N7 & N8 & N9 & N? & Total \\
\hline H1 & 3 & & & & & & & & 1 & & 4 \\
\hline $\mathrm{H} 2$ & 1 & & & & & & & & 1 & & 2 \\
\hline H3 & 3 & 1 & & & & & & 1 & & 3 & 8 \\
\hline H4 & & & & & 3 & & & & & & 3 \\
\hline H5 & & 2 & 1 & & & & & & 2 & & 5 \\
\hline H6 & & 3 & & & & & & 4 & & & 7 \\
\hline H7 & & & 2 & & & & & & 1 & & 3 \\
\hline H8 & & & & & & & & & & & 0 \\
\hline H9 & & 1 & & & & & & & & & 1 \\
\hline H10 & & 1 & & & & & 2 & & 3 & & 6 \\
\hline H11 & & & & & & & & & 4 & & 4 \\
\hline $\mathrm{H} 12$ & & & & & 2 & & & & & & 2 \\
\hline H13 & & 7 & & & & & & & 2 & 1 & 10 \\
\hline H14 & & & & & & & & & & & 0 \\
\hline H15 & & & & & & & & & & & 0 \\
\hline H16 & & & & & & & & & & & 0 \\
\hline $\mathrm{H} ?$ & & & & & & 1 & & & & & 1 \\
\hline Total & 7 & 15 & 3 & 0 & 5 & 1 & 2 & 5 & 14 & 4 & 56 \\
\hline
\end{tabular}
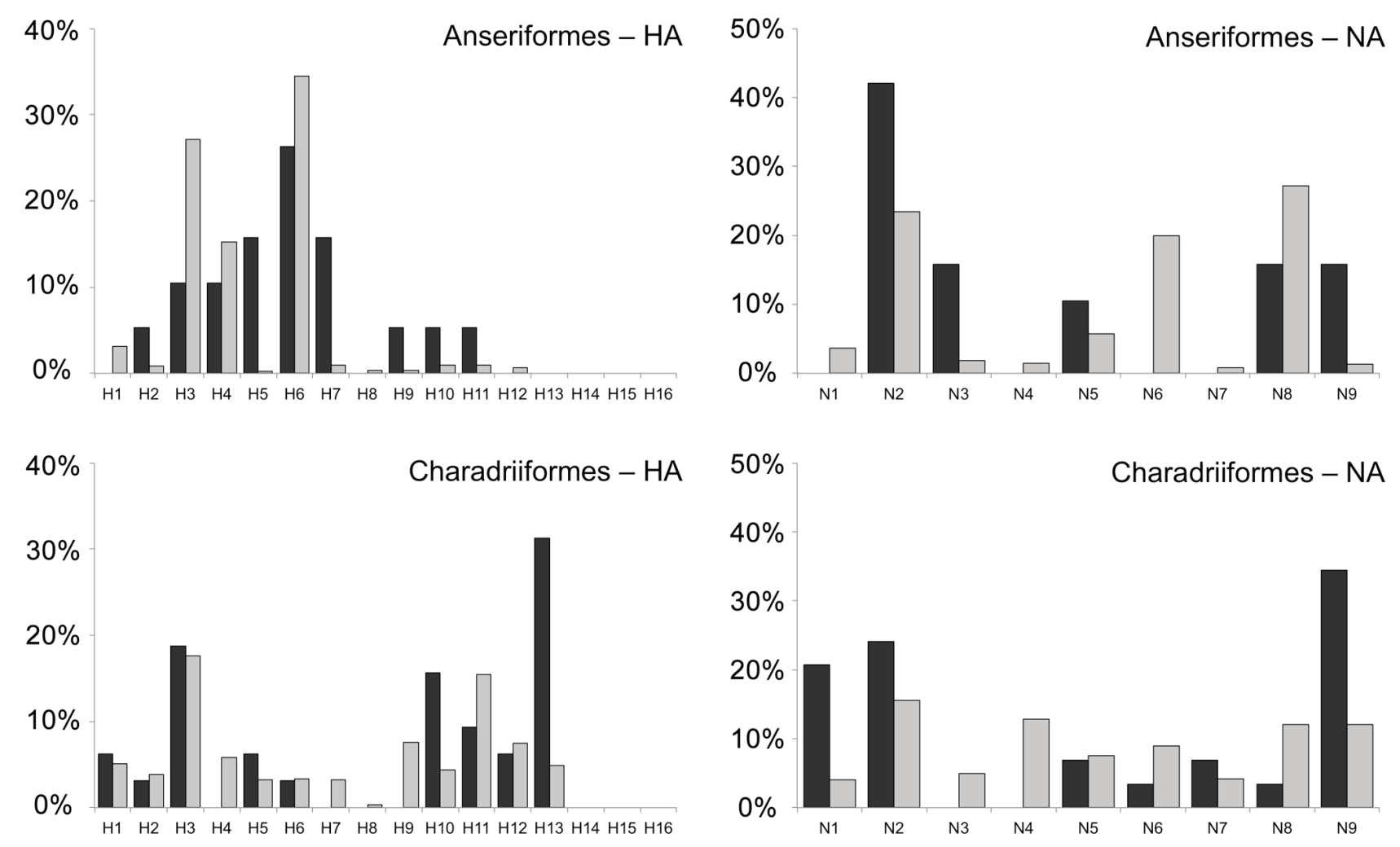

Fig. 4. Distribution of published AIV strains retrieved from wild Anseriformes and Charadriiformes in South America from 2006 to 2016 , in relation to the subtypes of hemagglutinin (HA) and neuraminidase (NA). Bar colors represent the continent from where the strains were obtained: South America (black) and North America (grey) (adapted from Krauss et al. 2004). ${ }^{13}$ 
Hurtado R. et al: Avian Influenza in Wild Birds from South America

PB2

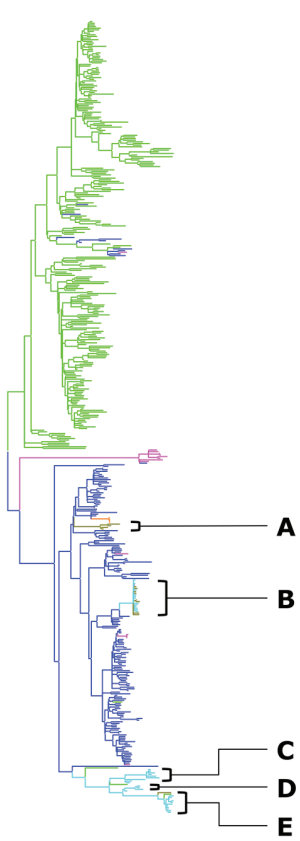

M

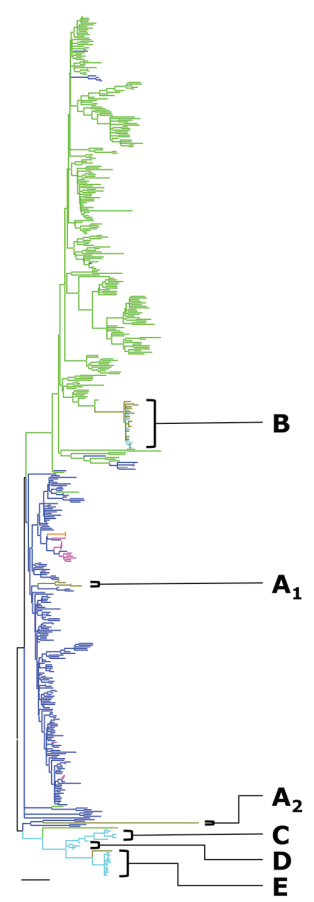

PB1

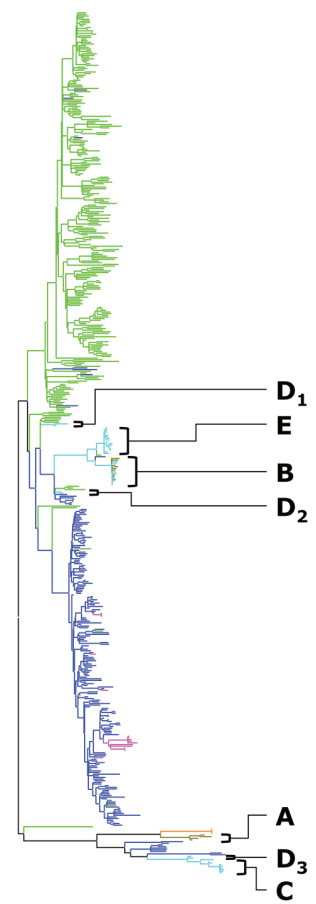

NP

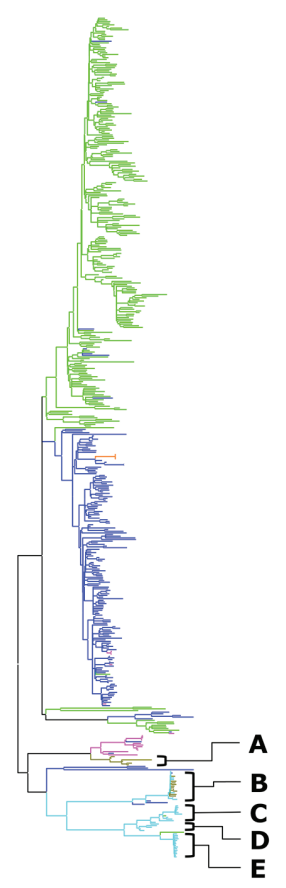

PA

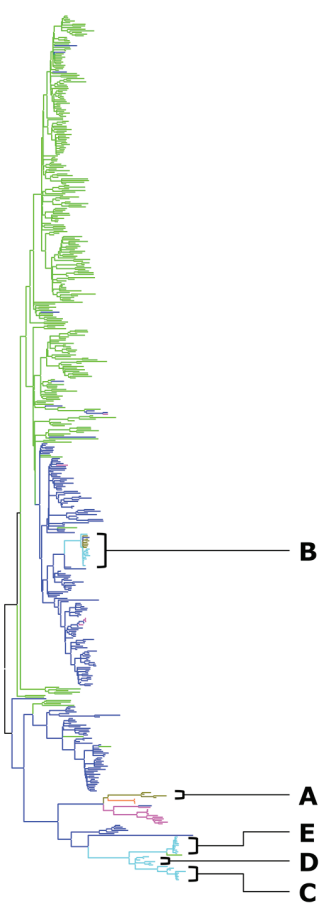

NS

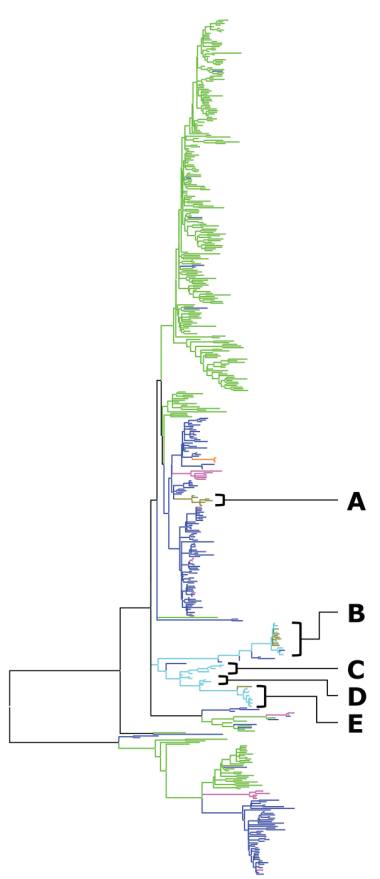

\footnotetext{
- Asia, Africa, Europe, Oceania (avian)

- North and Central America (avian)

- Antarctica (avian)
}

- South America (avian)

- South America (human) 
Table 5. Summary of the phylogenetic clusters of influenza strains retrieved from humans and other mammals in South America (see Fig. 5)

\begin{tabular}{lllll}
\hline Cluster & Hosts & Countries & Period & Subtypes \\
\hline A & equine & Argentina, Brazil, Chile, Uruguay & 1963 to 2006 & H3N8, H7N7 \\
B & human, swine & Argentina, Brazil, Colombia, Chile, Ecuador, Peru & 2009 to 2014 & H1N1, H1N2, H3N2 \\
C & human & Brazil, Chile, Colombia, Peru, Venezuela & 2000 to 2009 & H1N1 \\
D & human & Brazil, Chile, Uruguay, Venezuela & 1957 to 1983 & H1N1, H2N2, H3N2 \\
E & human, swine & Argentina, Chile, Colombia, Peru, Uruguay & 2007 to 2014 & H3N2 \\
\hline
\end{tabular}

shifts and reassortment to produce highly pathogenic strains.

Gene sequences are not available for all South American AIV isolates; however, those for which such information is available can be classified in two broad categories: (a) those whose genes are very closely related to those of AIV isolates obtained from wild birds in North America, indicating recent genetic interchange in the Americas; or (b) those presenting one or more gene sequences that are significantly distinct from those found elsewhere in the world, indicating an independent evolutionary pathway. Examples of the first category include AIV isolates obtained from wild birds in northern Brazil, Chile, Colombia and Peru. ${ }^{35,36,38,39,52}$ The second category is mainly represented by AIV isolates obtained from wild birds in northern Argentina, and to a smaller extent northeastern Brazil and Bolivia. ${ }^{33,40-42,48,49,53}$ An interesting exception is $\mathrm{A} /$ seagull/Chile/5775/2009/(H13N9), an isolate retrieved from a Franklin's gull (Larus pipixcan) in central Chile whose gene sequences cluster within the Eurasian clade. ${ }^{35,36}$ A possible explanation is that this strain is closely related to those from other gull species, such as the lesser black-backed gull (Larus fuscus), whose migratory routes extends longitudinally from North America to Europe, hence providing opportunities for intercontinental virus exchange. ${ }^{54}$

More broadly, however, it is fair to state that the genetics of South American isolates corroborate the hypothesis that there are Eurasian and American clades of AIV, and that genetic exchange between these continents is limited. ${ }^{11,55}$ Current evidence indicates there is extensive AIV gene flow between North and South America, which is likely due to the north-south organization of the flyways of migratory birds connecting these continents. ${ }^{35,38,52}$

\section{Implications for poultry health and wildlife conservation}

The 2002 avian influenza outbreak in Chile is a clear example of the important role that wild birds can play in the epidemiology of these viruses for the poultry industry. The outbreak of H7N3 in commercial poultry in Chile in 2002 was the first high pathogenicity AIV outbreak reported in birds in South America. The high pathogenicity avian influenza (HPAI) H7N3 strain involved in that outbreak was virtually identical to a low pathogenicity notifiable avian influenza (LPNAI) H7N3 strain that had already been circulating in domestic chickens in Chile, with the exception of an insertion of 30 nucleotides at the HA cleavage site. Because both the HPAI and LPNAI isolates from domestic chicken in Chile were genetically different from AIV isolates from other continents, they were proposed to represent a separate South American lineage, indicating that the virus had been circulating long enough in South America to diverge significantly from the North American or Eurasian viruses. ${ }^{56}$ At the time, it was speculated that the original source of the LPNAI strain was wild waterfowl, but unfortunately there were no isolates from local wild birds available for genetic comparison. However, further insight was provided by studies re- vealing that an LPNAI H7N3 strain obtained from a cinnamon teal sampled in Bolivia in 2001 had gene sequences that were closely related to those of the LPNAI strains from chickens in Chile in 2002. Because other genes of the cinnamon teal strain appeared to be from diverse sources, it was clear that genetic reassortment had occurred. ${ }^{48,49}$ While it was not possible to conclusively demonstrate that the LPNAI strain that was circulating in wild birds had been the original source of the chicken LPNAI strain (or viceversa), this case illustrates that AIV gene flow amongst wild and domestic birds can play a role in the maintenance and emergence of AIV strains that impact the poultry industry.

From a conservation standpoint, there is evidence from studies in other continents demonstrating that in some instances AIV can cause morbidity and mortality of wild birds..$^{12,14,57-59}$ In South America, Alvarez et al. were able to demonstrate that H1N1 infections had been the cause of severe illness and death of wild red-winged tinamous. ${ }^{33}$ The cleavage site of the HA antigen corresponded to that of a low pathogenicity avian influenza (LPAI) strain, although the clinical presentation (acute respiratory distress syndrome, lethargy, oculo-nasal discharge, swelling of the sinuses) and pathological findings (necropsy and histopathological analysis) clearly indicated that the virus was pathogenic for that species. This raises concern that red-winged tinamous may be unusually susceptible to AIV and therefore that their populations could be negatively affected by the spread of the virus, even by AIV strains that would not be theoretically classified as highly pathogenic to avian hosts. Considering the remarkable avian diversity of the South American continent and how little is known with regards to the susceptibility of bird species endemic to the Neotropics, further studies are urgently needed in order to evaluate the susceptibility to AIV infections across orders and families of South American birds (such as Tinamiformes). This concern is furthered by the findings of Ellis et al., who documented the impacts of an HPAI H5N1 outbreak in captive and semi-captive wild birds in Hong Kong, and found that New World species of Anseriformes had a higher influenza-related mortality than those from the Old World. ${ }^{58}$

\section{Phylogenetic relationship between AIV strains from humans} and wild birds

There are no known cases of human influenza in South America that could be directly related to transmission from wild birds. However, it is well established in other continents that wild birds play a key role in the maintenance and transmission of AIV, which may then be transferred to domestic animals and subsequently to humans, and it seems reasonable to suspect that a similar dynamic also takes place in South America. ${ }^{11,60}$ Through the reevaluation of the phylogeny of multiple AIV non-glycoprotein genes from South American AIV strains, it may be noted that isolates retrieved from humans and other mammals in South America can be broadly classified into five main groups (Fig. 5, Table 5; see Hurtado et al. for 
a detailed description of the methods). ${ }^{35}$

Group A comprises H3N8 and H7N7 strains retrieved from horses from 1963 to 2006 . The gene sequences of this group are relatively distinct from those identified in avian hosts worldwide, indicating a distinct evolutionary branch. Group A strains are not closely clustered to avian strains, however there are indications that these strains were historically derived from strains of wild birds. The gene sequences of group A are either within the broad North American clade (genes PB2, M and NS) or are in separate evolutionary branches that are shared with South American wild bird strains (genes PA and NP) and/or Antarctic wild bird strains (genes PB1 and PA). These patterns suggest that group A derives from strains that, at some point in the past, circulated and were disseminated by wild birds. An exception in this group is the A/ equine/SaoPaulo/4/1976/(H7N7) strain, which presents an unusual sequence for gene $M$ (indicated as $A_{2}$ in Fig. 5); although this strain's sequence for the gene $\mathrm{M}$ falls within the broad North American AIV clade, for unknown reasons it is highly distinct from all known AIV sequences.

Group B includes H1N1, H1N2 and H3N2 strains retrieved from humans and domestic swine from 2009 to the present. Strains of this group are closely related to AIV strains from turkeys in South and North America, A/turkey/Chile/2831765043/2009/ (H1N1) and A/turkey/Ontario/FAV11417/2009/(H1N1), indicating recent/on-going AIV transmission between mammals and birds. More broadly, the gene sequences of group B strains fall within the North American (genes PB2, PB1 and PA) or Eurasian clades (gene $\mathrm{M}$ ), indicating past genetic exchange with AIV strains that circulated in wild birds. For genes NP and NS, on the other hand, group B strains are part of separate evolutionary branches that are predominantly composed by strains retrieved from humans in South America but also include strains from chickens and turkeys from North America.

Group C is constituted by H1N1 strains that were retrieved from humans between 2000 to 2009 . The gene sequences of the strains in this group are remarkably distinct from those of all known avian strains and consistently are part of separate evolutionary branches, suggesting group $\mathrm{C}$ strains are probably specialized to infect humans and not transmitted from/to wild or domestic birds.

Group D comprises H1N1, H2N2 and H3N2 strains that were isolated from humans between 1957 and 1983. The gene sequences of this group are consistently clustered as part of the separate evolutionary branches along with those of group $\mathrm{C}$, with the exception of gene PB1. For this gene, the group is split into three subgroups (indicated as $\mathrm{D}_{1}, \mathrm{D}_{2}$ and $\mathrm{D}_{3}$ in Fig. 5) clustering either with strains from domestic birds from Eurasia $\left(D_{1}\right)$, with strains of wild birds from Australia and North America $\left(D_{2}\right)$, or with strains from group $\mathrm{C}\left(\mathrm{D}_{3}\right)$.

Lastly, group E encompasses H3N2 strains isolated from humans and swine from 2007 to the present. For most genes, the sequences of this group are also part of the separate evolutionary branches along with groups $\mathrm{C}$ and $\mathrm{D}$; the only exception was gene PB1, for which group E strains formed a separate evolutionary branch along with group B. Interestingly, two Chinese duck AIV strains frequently clustered along with this group, A/duck/Zhejiang/LS02/2014/(H7N9) and A/duck/Jiangsu/1MA/2008/(H9N2).

When the distinct evolutionary paths of these groups are contemplated in their ensemble, it becomes clear that the gene flow of AIV among birds and humans and other mammals in South America is a fluid mosaic. While some gene segments are part of the North American clade and therefore probably originated from the broader wild bird AIV gene pool that circulates in the Western hemisphere, in most cases these segments are significantly divergent which indicates that they then followed distinct evolution- ary paths, with limited genetic interchange with avian strains. The main exception to this broader picture is group B, which comprises AIV strains for which the gene sequences suggest there is still recent/on-going shared transmission among humans, swine and turkeys.

\section{Implications for human health}

While strains of the subtypes $\mathrm{H} 1$ and $\mathrm{H} 3$ are well-established as human pathogens, often with highly efficient human-to-human transmission and relatively low lethality, other subtypes typically associated with birds, such as strains of the subtypes H5 and H7, will tend to be transmitted less effectively among humans but will lead to more severe infections with higher lethality. ${ }^{61,62}$ This difference in transmission is thought to be related to differences in affinity and anatomical distribution of the sialic acid-linked receptors to which HA binds, with highly pathogenic $\mathrm{H} 5$ strains predominantly infecting lower sections of the human respiratory tract. ${ }^{62}$

Most human cases of $\mathrm{H} 5$ and $\mathrm{H} 7$ infection have been linked to direct interaction with live poultry, particularly workers of the poultry industry and people visiting live poultry markets. ${ }^{61,63}$ Less frequent cases of human infections by subtypes $\mathrm{H} 9$ and $\mathrm{H} 10$, which usually only produce mild disease, have also been linked to contact with domestic birds. ${ }^{64,65}$ In this sense, it seems probable that the main opportunities for viruses that circulate in wild birds in South America to be transferred to humans would be through domestic animals serving as a bridge for transmission. The phylogenetic evidence for recent/on-going AIV genetic interchange between humans, swine and turkeys (e.g. phylogenetic group B) corroborates this possibility, as does the past evidence for genetic exchange between wild and domestic birds in South America. ${ }^{48,49}$

The presence of wild birds entering poultry farms and interacting with domestic birds might therefore play a highly significant role in South America as an interface for genetic flow from wild birds to domestic birds and then to humans. Recent studies have demonstrated that synanthropic species of Passeriformes and Columbiformes may interact directly or indirectly with chickens in poultry farms in South America. ${ }^{66,67}$ Although no evidence of AIV infection was detected thus far in such synanthropic birds near poultry facilities, such studies stress the need for the development and implementation of biosecurity measures that effectively prevent wild birds from closely interacting with poultry in farms. ${ }^{67}$

Although domestic birds may pose the most significant risk in terms of AIV gene flow from wild birds to humans, the possibility of direct AIV transmission from wild birds to humans should not be dismissed. For instance, traditional communities from some regions of South America may engage in cultural practices that provide opportunities for the transmission of AIV. One such example is the illegal trade of game meat in some regions of the Amazon. ${ }^{68}$ Another example are the remote fishing communities along the Amazon coast of Brazil, where capturing and maintaining aquatic birds, captive in precarious domestic environments, is a common practice, whether for meat consumption (Anseriformes) or to serve as pets (Charadriiformes) ${ }^{69}$ It is acutely concerning that in one community where this practice is frequent, the swab of a captive white-faced whistling duck (Dendrocygna viduata) had detectable traces of AIV genetic material. ${ }^{43}$

Besides indigenous and traditional communities that hunt or interact otherwise with wild birds throughout the continent, sport hunters may also be at risk. For instance, Alvarez et al. identified AIV as the cause of death of red-winged tinamous at hunting grounds. ${ }^{33}$ This occurred less than $50 \mathrm{~km}$ from Buenos Aires 
city, and the AIV strain identified in that study belonged to subtype H1N1, an antigenic subtype that is well-documented to be compatible with human infections, including in pandemics. ${ }^{9,10}$ It is, therefore, clear that AIV surveillance in wild birds should be a strategic component in preparing for and responding to influenza epidemics in humans in South America. ${ }^{70}$ Lastly, it is worth noting that researchers, rehabilitators, veterinarians, conservationists and other professionals working with wild birds may also be at risk of exposure, and should at all times adopt biosecurity measures while working with these animals, especially when it comes to the use personal protective equipment.

\section{Directions for the future}

The fragmented and discontinuous nature of research efforts and the lack of long-term national and international surveillance programs have limited our understanding of the regional characteristics of AIV ecology in South America. The South American continent has unique ecosystems, avian communities and environmental conditions, which may potentially lead to differences in the ecology and epidemiology of AIV in relation to other well-studied regions, such as North America, and, therefore, we cannot assume that data from other continents can be extrapolated to South America without the need of confirmatory studies.

For these reasons, while it is vital to conduct targeted surveillance of bird groups that are well-established as reservoirs of infection for these viruses, namely Anseriformes and Charadriiformes, moving forward it will also be important to examine whether other avian taxa could play a distinct role in the ecology of AIV in South America. In particular, groups such as Phoenicopteriformes (flamingoes), Procellariiformes (albatrosses, petrels), Sphenisciformes (penguins) and Suliformes (cormorants, gannets) have characteristics and behaviors that could lead them to play a role in the epidemiology of AIV. Furthermore, it is also worth examining whether South American endemic groups of terrestrial birds (e.g. Tinamiformes, Rheiformes) are susceptible to AIV infections.

With regards to the geographic distribution of the study effort, surveillance will benefit from monitoring stop-over and wintering sites along the flyways of migratory aquatic birds. ${ }^{39-41,69}$ However, considering the ecological and landscape diversity of the continent, it is important to also dedicate sampling effort to other areas to evaluate regional and biome-specific differences in AIV epidemiology. Additionally, valuable insight may be obtained by investigating the occurrence of AIV in wild birds in areas where there might be a closer interaction among humans, domestic and wild birds, such as swine and poultry farms, hunting grounds, and communities where subsistence hunting and domestication of wild birds is common practice. ${ }^{33,41,43,66,67}$

Lastly, it is important to underline that the failure of many publications to provide detailed information on the sampling effort has limited a comprehensive meta-analysis of the literature on AIV in wild birds in South America. Although it is understandable that scientific journals need to impose restrictions on article length, authors should bear in mind that supplementary files are a valuable alternative to provide detailed datasets that greatly extends the value and contribution of any given publication. We, therefore, urge researchers to use supplementary files to provide extensive details on the sampling effort (e.g. species, location, GPS coordinates, date, etc. for each sample) and diagnostic results of their studies (e.g. cycle threshold values, detailed pathobiology testing results, etc.). Such details should be provided not only for samples with confirmed positive results but also for samples that were positive or inconclusive in screening tests (e.g. rRT-PCR) but that could not be confirmed by subsequent tests, and also for samples that were negative. Furthermore, it is essential to make every effort to sequence all eight genome segments of the virus of every AIV isolate, and to deposit these sequences in publicly-available databases (such as GenBank).

\section{Conclusion}

Although avian influenza virus is one of the most studied pathogens in the world, studies on the ecology and epidemiology of these viruses in South America are few and fragmented. Current evidence corroborates that many of the broad epidemiological patterns that have been documented in other continents, such as the role played by Anseriformes and Charadriiformes in the maintenance and spread of AIV, are also true in South America. On the other hand, the fact that AIV prevalence in South American studies appears to be remarkably lower than that observed in other continents, along with the presence of endemic taxa of birds that may be highly susceptible to AIV, indicates that South America may have distinct characteristics that modulate the epidemiology of AIV in unique ways. The last decade has witnessed the emergence of a South American research community dedicated to investigating this virus, resulting in a significant number of studies being published in recent years. However, our knowledge on the occurrence of avian influenza in South America is still limited and there are important gaps in the species and geographic distribution of the sampling effort.

\section{Acknowledgments}

We are grateful to the São Paulo Research Foundation (No. 2009/10695-0) and the Coordination for the Improvement of Higher Education Personnel (CAPES).

\section{Conflict of interest}

The authors have no conflict of interests related to this publication.

\section{Author contributions}

Compiled and analysed the data (RH, RETV), drafted and revised the manuscript (RH, RETV).

Supplementary information

(Supplementary information is linked to the online version of the paper on the Exploratory Research and Hypothesis in Medicine website.)

\section{References}

[1] Webster RG, Shortridge KF, Kawaoka Y. Influenza: interespecies transmission and emergence of new pandemics. FEMS Immunol Med Microbiol 1997;18(4):275-279. doi:10.1111/j.1574-695X.1997.tb01056.x.

[2] Fouchier RA, Munster V, Wallensten A, Bestebroer TM, Herfst S, Smith D, et al. Characterization of a novel influenza A virus hemagglutinin subtype (H16) obtained from black-headed gulls. J Virol 2005;79(5):2814-2822. doi:10.1128/ 
JVI.79.5.2814-2822.2005.

[3] Tong S, Li Y, Rivailler P, Conrardy C, Castillo DAA, Chen LM, et al. A distinct lineage of influenza A virus from bats. Proc Nat Acad Sci USA 2012;109(11):4269-4274. doi:10.1073/pnas.1116200109.

[4] Tong S, Zhu X, Li Y, Shi M, Zhang J, Bourgeois M, et al. New World bats harbor diverse influenza A viruses. PLoS Pathog 2013;9(10):e1003657. doi:10.1371/journal.ppat.1003657.

[5] Moreira ÉA, Locher S, Kolesnikova L, Bolte H, Aydillo T, García-Sastre A, et al. Synthetically derived bat influenza A-like viruses reveal a cell type- but not species-specific tropism. Proc Natl Acad Sci U S A 2016;113(45):1279712802. doi:10.1073/pnas.1608821113.

[6] Morens DM, Fauci AS. The 1918 Influenza Pandemic: Insights for the 21st Century. J Inf Dis 2007;195:1018-1028. doi:10.1086/511989.

[7] Lina B. History of influenza pandemics. In: Raoult D, Drancourt M, editors Paleomicrobiology: past human infections. Berlin: Springer-Verlag; 2008:199 211.

[8] Potter CW. Chronicles of influenza pandemics. In: Nicholson KG, Webster RG, Hay AJ, editors. Textbook of influenza. Oxford: Blackwell Science; 1998:3-18

[9] Taubenberger JK, Reid AH, Janczewski TA, Fanning TG. Integrating historical, clinical and molecular genetic data in order to explain the origin and virulence of the 1918 Spanish influenza virus. Phil Trans Royal Soc Lon B Biol Sc 2001;356(1416):1829-1839. doi:10.1098/rstb.2001.1020.

[10] Dawood FS, Danielle Iuliano A, Reed C, Meltzer MI, Shay DK, Cheng PY, et al. Estimated global mortality associated with the first 12 months of 2009 pandemic influenza A H1N1 virus circulation: a modelling study. Lancet Infect Dis 2012;12(9):687-695. doi:10.1016/S1473-3099(12)70121-4.

[11] Olsen B, Munster VJ, Wallensten A, Waldenstrom J, Osterhaus ADME, Fouchier RAM. Global patterns of influenza A virus in wild birds. Science 2006;312(5772):384-388. doi:10.1126/science.1122438.

[12] Fouchier RA, Munster V, Keawcharoen J, Osterhaus ADME, Kuiken T. Virology of avian influenza in relation to wild birds. J Wildl Dis 2007:43(3):S7-S14.

[13] Krauss S, Walker D, Pryor SP, Niles L, Chenghong L, Hinshaw VS, et al. Influenza A viruses of migrating wild aquatic birds in North America. Vector Borne Zoonotic Dis 2004;4(3):177-189. doi:10.1089/vbz.2004.4.177.

[14] Hanson BA, Luttrell MP, Goekjian VH, Niles L, Swayne DE, Senne DA, et $a l$. Is the occurrence of avian influenza virus in Charadriiformes species and location dependent? J Wildl Dis 2008;44(2):351-361. doi:10.7589/0090-355844.2.351.

[15] Bahl J, Krauss S, Kühnert D, Fourment M, Raven G, Pryor SP, et al. Influenza A virus migration and persistence in North American wild birds. PLoS Pathog 2013;9(8):e1003570. doi:10.1371/journal.ppat.1003570.

[16] Boere GC, Stroud DA. The flyway concept: what it is and what it isn't. In: Boere GC, Galbraith CA, Stroud DA, editors. Waterbirds around the world. Edinburgh: The Stationery Office; 2006:40-47.

[17] Kawamoto AHN, Mancini DAP, Pereira LE, Cianciarullo AM, Cruz AS, Dias $\mathrm{ALF}$, et al. Investigation of influenza in migrating birds, the primordial reservoir and transmitters of influenza in Brazil. Braz J Microbiol 2005;36(1):88-93. doi: $10.1590 /$ S1517-83822005000100017

[18] Aranku MMC, Faria WDEC, Takeyama DC. Influenza aviária em aves silvestres brasileiras - inquérito sorológico através da imunodifusão. Rev Inst Med Trop São Paulo 1971;13:292-296.

[19] Oliveira JG Jr, Belluci MSP, Vianna JSM, Mazur C, Andrade CM, Fedullo LPL, et al. Avaliação soroepidemiológica do vírus influenza em aves domésticas e silvestres no estado do Rio de Janeiro. Arq Bras Med Vet Zootec 2001;53(3):299-302

[20] Couceiro JN, Machado RD, Chaves JR. Influenza A, isolation and characterization of virus isolated from wild birds. An Microbiol (Rio J) 1982;27:193-204.

[21] Couceiro JN, Chaves JR, Brandão CT, Machado R. Isolation and characterization of influenza virus type A, in ornamental birds, in Rio de Janeiro. An Microbiol (Rio J) 1982;27:159-167

[22] Soares PB, Demétrio C, Sanfilippo L, Kawamoto AH, Brentano L, Durigon EL. Standardization of a duplex RT-PCR for the detection of influenza A and Newcastle disease virus in migratory birds. J Virol Methods 2005;123(2):125-130. doi:10.1016/j.jviromet.2004.09.011.

[23] Kawamoto AHN. Caracterização molecular e sorológica da influenza A isolada de aves residentes, silvestres e migratórias no estado de São Paulo [Dissertation]. São Paulo: University of São Paulo; 2013.

[24] SVS. Inquérito sorológico em aves migratórias e residentes de Galinhos-RN para detecção do vírus da febre do Nilo ocidental e outros vírus. Brazil: Secretaria de Vigilância em Saúde [updated 2004 Feb 19; cited 2016 Oct 01]. Available from: <http://bvsms.saude.gov.br/bvs/periodicos/boletim_eletronico_epi ano04_n02.pdf>.

[25] SVS. Segundo inquérito sorológico em aves migratórias e residentes do Parque Nacional da Lagoa do Peixe/RS para detecção do vírus da febre do Nilo Ocidental e outros vírus. Brazil: Secretaria de Vigilância em Saúde [updated 2004 June 21; cited 2016 Oct 01]. Available from: <http://bvsms.saude.gov.br/bvs/ periodicos/boletim eletronico epi ano04 n05.pdf>.

[26] UNSD. 2011 Demographic Yearbook - Table 3: Population by sex, rate of population increase, surface area and density. United Nations Statistics Division [updated 2012 Dec 11; cited 2016 Oct 02]. Available from: <http://unstats.un.org/
unsd/demographic/products/dyb/dyb2011/Table03.pdf>.

[27] Lepage D. Avibase - Bird Checklists of the World. Canada: Bird Studies Canada [updated 2016 Oct 02 ; cited 2016 Oct 02]. Available from: <http://avibase.bsceoc.org/checklist.jsp>.

[28] Gaidet N, Mamy ABOE, Capelle J, Caron A, Cumming GS, Grosbois V, et al. Investigating avian influenza infection hotspots in Old-World shorebirds. PLoS One 2012;7(9):e46049. doi:10.1371/journal.pone.0046049.

[29] Hurt A, Su YCF, Aban M, Peck H, Lau H, Baas C, et al. Evidence for the introduction, reassortment and persistence of diverse influenza A viruses in Antarctica. J Virol 2016;90(21):9674-9682. doi:10.1128/JVI.01404-16.

[30] Hurt A, Vijaykrishna D, Butler J, Baas C, Maurer-Stroh S, Silva-de-la-Fuente $\mathrm{MC}$, et al. Detection of evolutionarily distinct avian influenza A viruses in Antarctica. mBio 2014;5(3):e01098-14. doi:10.1128/mBio.01098-14

[31] Granter A, Wille M, Whitney H, Roberston GJ, Ojkic D, Land AS. The genome sequence of an H11N2 avian influenza virus from a Thick-billed Murre (Uria lomvia) shows marine-specific and regional patterns of relationships to other viruses. Virus Genes 2010;41(2):224-230. doi:10.1007/s11262-010-0504-5.

[32] Lang AS, Lebarbenchon C, Ramey AM, Robertson GJ, Waldenström J, Wille M. Assessing the role of seabirds in the ecology of influenza A viruses. Avian Dis 2016;60:378-386. doi:10.1637/11135-050815-RegR.

[33] lvarez P, Mattiello R, Rivailler P, Pereda A, Davis CT, Boado L, et al. First isolation of an $\mathrm{H} 1 \mathrm{~N} 1$ avian influenza virus from wild terrestrial non-migratory birds in Argentina. Virology 2010;396(1):76-84. doi:10.1016/j.virol.2009.10.009.

[34] Olson DM, Dinerstein E, Wikramanayake ED, Burgess ND, Powell GVN, Underwood EC, et al. Terrestrial ecoregions of the world: a new map of life on Earth. BioScience 2001;51(11):933-938.

[35] Hurtado R, Fabrizio T, Vanstreels RET, Krauss S, Webby RJ, Webster RG, et al. Molecular characterization of subtype H11N9 avian influenza virus isolated from shorebirds in Brazil. PLoS One 2015;10(12):e0145627. doi:10.1371/jour nal.pone. 0145627.

[36] Mathieu C, Moreno V, Pedersen J, Jeria J, Agredo M, Gutiérrez C, et al. Avian Influenza in wild birds from Chile, 2007-2009. Virus Res 2015;199:42-45. doi:10.1016/j.virusres.2015.01.008.

[37] Ghersi BM, Blazes DL, Icochea E, Gonzalez RI, Kochel T, Tinoco Y, et al. Avian influenza in wild birds, central coast of Peru. Emerg Infect Dis 2009;15(6):935-938. doi:10.3201/eid1506.080981

[38] Karlsson EA, Ciuoderis K, Freiden PJ, Seufzer B, Jones JC, Johnson J, et al. Prevalence and characterization of influenza viruses in diverse species in Los Llanos, Colombia. Emerg Microbes Infect 2013;2(4):e20. doi:10.1038/emi.2013.20.

[39] Araújo J, Azevedo-Júnior SM, Gaidet N, Hurtado RF, Walker D, Thomazell LM, et al. Avian influenza virus (H11N9) in migratory shorebirds wintering in the Amazon region, Brazil. PLoS One 2014;9(10):e110141. doi:10.1371/journal.pone. 0110141

[40] Pereda AJ, Uhart M, Perez AA, Zaccagnini ME, La Sala L, Decarre J, et al. Avian influenza virus isolated in wild waterfowl in Argentina: evidence of a potentially unique phylogenetic lineage in South America. Virology 2008;378(2):363-370. doi:10.1016/j.virol.2008.06.010

[41] Rimondi A, Xu K, Craig MI, Shao H, Ferreyra H, Rago MV, et al. Phylogenetic analysis of $\mathrm{H} 6$ influenza viruses isolated from rosy-billed pochard (Netta peposaca) in Argentina reveals the presence of different HA gene clusters. J Virol 2011;85(24):13354-13362. doi:10.1128/JVI.05946-11.

[42] Xu K, Ferreri L, Rimondi A, Olivera V, Romano M, Ferreyra H, et al. Isolation and characterization of an H9N2 influenza virus isolated in Argentina. Virus Res 2012;168(1-2):41-47. doi:10.1016/j.virusres.2012.06.010.

[43] Hurtado R, Azevedo-Júnior SM, Vanstreels RET, Fabrizio T, Walker D, Rodrigues RC, et al. Surveillance of avian influenza virus in aquatic birds on the Brazilian Amazon coast. EcoHealth 2016;13(4):813-818. doi:10.1007/s10393016-1169-x.

[44] Pinto LB, Ometto T, Araújo J, Thomazelli LM, Seixas MM, Barbosa CM, et al. Investigation of influenza A, West Nile and Newcastle disease viruses in birds from the Pantanal wetlands of Mato Grosso, Brazil. Brazilian J Poultry Sci 2016;18(2):291-298. doi:10.1590/1806-9061-2015-0111.

[45] Livezey BC. A phylogenetic analysis of recent Anseriform genera using morphological characters. Auk 1986;103(4):737-754

[46] Kawaoka Y, Chambers TM, Sladen WL, Webster RG. Is the gene pool of influenza viruses in shorebirds and gulls different from that in wild ducks? Virol 1988;163(1):247-250.

[47] Stallknecht DE, Brown JD. Ecology of avian influenza in wild birds. In: Swayne DE, editor. Avian influenza. Oxford: Blackwell Publishing; 2008:43-58.

[48] Spackman E, McCracken KG, Winker K, Swayne DE. H7N3 avian influenza virus found in a South American wild duck is related to the Chilean 2002 poultry outbreak, contains genes from equine and North American wild birds lineages, and is adapted to domestic turkey. J Virol 2006;80(15):7760-7764. doi:10.1128/JVI.00445-06.

[49] Spackman E, McCracken KG, Winker K, Swayne DE. An avian influenza virus from waterfowl in South America contains genes from North American avian and equine lineages. Avian Dis 2007;51(1 Suppl):273-274. doi:10.1637/7529032106R.1.

[50] Senne DA. Avian influenza in North and South America, the Caribbean, and Australia, 2006-2008. Avian Dis 2010;54(1 Suppl):179-186. doi:10.1637/8921- 


\section{Hurtado R. et al: Avian Influenza in Wild Birds from South America}

050809-Review.1.

[51] Ghersi BM, Sovero MM, Icochea E, Gonzalez RI, Blazes DL, Gonzalez AE, et al. Isolation of low-pathogenic H7N3 avian influenza from wild birds in Peru. J Wildl Dis 2011;47(3):792-795. doi:10.7589/0090-3558-47.3.792.

[52] Nelson MI, Pollett S, Ghersi B, Silva M, Simons MP, Icochea E, et al. The genetic diversity of influenza A viruses in wild birds in Peru. PLoS One 11(1):e0146059. doi:10.1371/journal.pone.0146059.

[53] Obenauer JC, Denson J, Mehta PK, Su X, Mukatira S, Finkelstein DB, et al. Large-scale sequence analysis of avian influenza isolates. Science 2006;311(5767):1576-1580. doi:10.1126/science.1121586.

[54] Hallgrimsson GT, Swelm NDV, Gunnarsson HV, Johnson TB, Rutt CL. First two records of European-banded lesser black-backed gulls Larus fuscus in America. Mar Ornithol 2011;39:137-139.

[55] Krauss S, Obert C A, Franks J, Walker D, Jones K, Seiler P, et al. Influenza of migratory birds and evidence of limited intercontinental virus exchange. PLoS Pathog 2007;3(11):e167. doi:10.1371/journal.ppat.0030167.

[56] Suarez DL, Senne DA, Banks J, Brown IH, Essen SC, Lee C, et al. Recombination resulting in virulence shift in avian influenza outbreak, Chile. Emerg Infect Dis 2004;10:693-699. doi:10.3201/eid1004.030396.

[57] Becker WB. Isolation and classification of tern virus: Influenza Virus A/Tern/ South Africa/1961. J Hyg 1966;64(3):309-320.

[58] Ellis TM, Bousfield RB, Bissett LA, Dyrting KC, Luk GSM, Tsim ST, et al. Investigation of outbreaks of highly pathogenic $\mathrm{H} 5 \mathrm{~N} 1$ avian influenza in waterfowl and wild birds in Hong Kong in late 2002. Avian Pathol 2004;33(5):492505. doi:10.1080/03079450400003601.

[59] Liu J, Xiao H, Lei F, Zhu Q, Qin K, Zhang XW, et al. Highly pathogenic H5N1 influenza virus infection in migratory birds. Science 2005;309:1206. doi:10.1126/science. 1115273 .

[60] Cox NJ, Subbarao K. Global epidemiology of influenza: past and present. Ann Rev Med 2001;51:407-421. doi:10.1146/annurev.med.51.1.407.

[61] Beigel JH, Farrar J, Han AM, Hayden FG, Hyer R, de Jong MD, et al. Avian influenza A (H5N1) infection in humans. N Engl J Med 2005;353:1374-1385. doi:10.1056/NEJMra052211.

[62] van Riel D, Munster VJ, de Wit E, Rimmelzwaan GF, Fouchier RA, Osterhaus $\mathrm{AD}$, et al. $\mathrm{H} 5 \mathrm{~N} 1$ virus attachment to lower respiratory tract. Science 2006;312(5772):399. doi:10.1126/science.1125548.

[63] Belser JA, Bridges CB, Katz JM, Tumpey TM. Past, present, and possible future human infection with influenza virus A subtype H7. Emerg Infect Dis 2009;15(6):859-865. doi:10.3201/eid1506.090072.

[64] Arzey GG, Kirkland PD, Arzey KE, Frost M, Maywood P, Conaty S, et al. Influenza virus A (H10N7) in chickens and poultry abattoir workers, Australia. Emerg Infect Dis 2012;18(5):814-816. doi:10.3201/eid1805.111852.

[65] Huang Y, Li X, Zhang H, Chen B, Jiang Y, Yang L, et al. Human infection with an avian influenza A (H9N2) virus in the middle region of China. J Med Virol 2015;87(10):1641-1648. doi:10.1002/jmv.24231.

[66] Scherer AL, Scherer JFM, Petry MV, Sander M. Occurrence and interaction of wild birds at poultry houses in Southern Brazil. Braz J Ornithol 2011;19(1):74 79.

[67] Guimarães MB, Hurtado R, Bello CP, Vanstreels RET, Ferreira AJP. Surveillance for Newcastle disease virus, avian influenza virus and Mycoplasma gallisepticum in wild birds near commercial poultry farms surrounded by Atlantic forest remnants, Southeastern Brazil. Braz J Poultry Sci 2016;18(3):387-394. doi:10.1590/1806-9061-2015-0164.

[68] Baía Júnior PC, Guimarães DA, Le Pendu Y. Non-legalized commerce in game meat in the Brazilian Amazon: a case study. Int J Trop Biol 2010;58(3):1079 1088 .

[69] Hurtado R, Vanstreels RET, Serafini PP, Azevedo-Júnior SM, Durigon EL. Aquatic wild birds kept captive at remote coastal communities in Northern Brazil. Boletín Chileno de Ornitología 2014;20:17-22.

[70] Powdrill TF, Nipp TL, Rinderknecht JL. One health approach to influenza: assessment of critical issues and options. Emerg Infect Dis 2010;16(8):e1. doi:10.3201/eid1608.100673. 